Review Article

Open Access

\title{
Supply Chain of the Molluscan Shellfish: Overview of Key Food Safety Issues
}

\author{
Patrizia Serratore \\ Senior Researcher, Department of Veterinary Medical Science, University of Bologna, Italy
}

\section{Article Info}

*Corresponding author:
Patrizia Serratore
Senior Researcher
Department of Veterinary Medical Science
University of Bologna
Special Operative Unit of Aquaculture and
Hygiene of Fishery Production
Itlay
Tel: +390547338941
Fax: +390547338941
E-mail: patrizia.serratore@unibo.it

Received: October 4, 2017

Accepted: November 3, 2017

Published: March 13, 2018

Citation: Serratore P. Supply Chain of the Molluscan Shellfish: Overview of Key Food Safety Issues. Madridge J Food Technol. 2018; 3(1): 98-107.

doi: $10.18689 / \mathrm{mjft}-1000115$

Copyright: (c) 2018 The Author(s). This work is licensed under a Creative Commons Attribution 4.0 International License, which permits unrestricted use, distribution, and reproduction in any medium, provided the original work is properly cited.

Published by Madridge Publishers

\begin{abstract}
Molluscan shellfish (hereafter, shellfish), together with finfish, crustaceans and other mollusks, are among the most internationally traded food commodities. Shellfish are low in fat, with a high concentration of monounsaturated and polyunsaturated fat, and provide high quality protein for the human diet, but their consumption, particularly raw or undercooked, is not risk-free. In fact these animals consume organic material through the flow of water from their aquatic environment by specialized filtration systems, and in this way they can hold and even concentrate contaminants, including harmful bacteria and viruses, chemicals and marine biotoxins. From an epidemiological point of view, the foodborne diseases of major concern linked to the consumption of shellfish are caused by enteroviruses, as Noroviruses (NoVs) and Hepatitis A virus (HAV), and pathogenic marine bacteria, as $V$. parahaemolyticus and $V$. vulnificus. Considering that it is impossible to determine whether shellfish are contaminated with pathogenic microorganisms without microbiological testing, it is very important to control them at the origin (monitoring of the growing areas) or eliminate them by post-harvest treatments. This review will focus on the key safety issues of the supply chain of shellfish, having regard with the regulatory and supervision rules established in Europe and U.S, with the specific aim to point out criticisms.
\end{abstract}

Keywords: Shellfish safety; Growing areas; Post-harvest treatments.

\section{Introduction}

Molluscan shellfish, hereafter referred to as shellfish, together with gastropods constitute over $80 \%$ of the described living marine molluscan species [1], and represent important food sources for humans. Shellfish has traditionally been a major component of world aquaculture, and FAO recorded statistics from 187 countries and territories worldwide with aquaculture production in 2012 [2].

The distinctive feature of shellfish aquaculture is that these animals are cultivated without feeding, and without fertilizers, pesticides, herbicides utilization, therefore they are very good candidates for an organic production. Even if the consumption of organic seafood still represent a niche and a new market in the EU, accounting for $1 \%$ in the main EU consumer countries [3], it is possible to state that demand for organic aquaculture products has grown rapidly over the last years. This is also true for the U.S. market, where organic seafood account only for $1.5 \%$ of the total aquaculture production, but with an annual growth rate of $3.6 \%$ in the last years [4].

Among the marine shellfish, a total of 180 species have long been a part of the diet of coastal human populations [5]. Over time, and through the development of suitable facilities for food processing, storage and transport, the consumption of fisheries and aquaculture products has extended beyond the coastal areas reaching hundreds of millions of people around the world. 
Geopolitics has also played a decisive role in advancing and reinforcing this structural trend, and all these factors increased the shift from local consumption to international markets, reaching a global per capita consumption to above 20 kilograms [6].

In this scenario, production and trade of shellfish play an important role, even if it is mostly concentrated on four species [7], as reported in figure 1 .

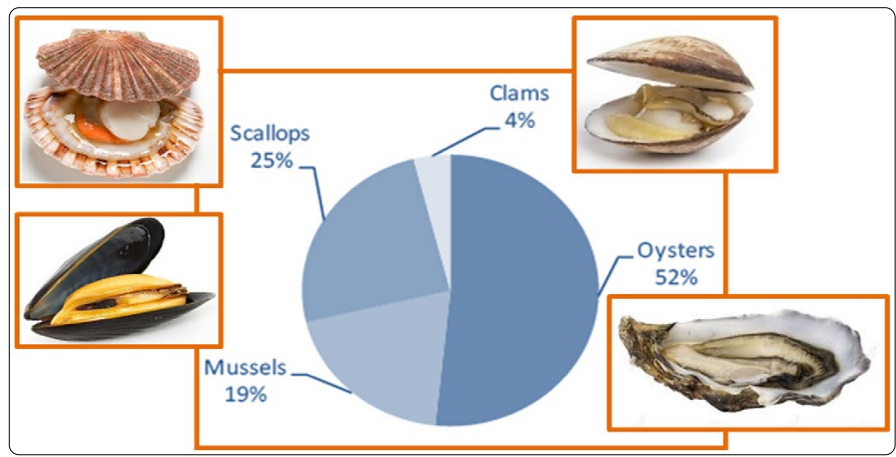

Figure 1. Shellfish production by selected species, both wild and farmed. Adapted from FAO data [7].

On the basis of the last available data, the global aquaculture production of shellfish has been $16.1 \mathrm{Mt}$, and China, with $12 \mathrm{Mt}$ representing 5 times the total production of the rest of the world, is the leading producer. Other major Asian shellfish producers include Japan (377 kt), the Republic of Korea (347 kt) and Thailand (210 kt). The U.S. production has been $160.5 \mathrm{kt}$, about a quarter of the European production, with $632 \mathrm{kt}$, of which 223 from Spain, 155 from France and 111 from Italy [6].

Notwithstanding the high level of production, the EU is entirely self-sufficient only for the mussels demand, confirming that it is a major consumption market and the largest importer of seafood products, making up $24 \%$ of the total value of world trade [8].

On the other hand, the world shellfish market was impacted by currency changes, including the relatively lower value of the euro against the U.S. dollar, therefore EU countries reported lower bivalve imports, particularly the Spanish mussel processing industry, which moved back to domestic products [7].

Shellfish are low in fat, with a higher concentration of monounsaturated and polyunsaturated fat, and provide high quality protein with all the dietary-essential amino acids for maintenance and growth of the human body [9].

Regardless these nutritional properties, the consumption of shellfish, particularly raw or undercooked, is not risk-free. In fact these animals consume organic material through the flow of water from their aquatic environment by specialized filtration systems, and in this way they can hold and even concentrate contaminants, including harmful bacteria and viruses [10].

Moreover, toxins-producing microscopic planktonic algae represent a critical food for shellfish, because the toxins remains in their system, even if normally in amounts too small to be harmful. In any case, favorable conditions, as a combination of warm temperatures, sunlight, and nutrient- rich waters, can cause rapid plankton reproduction, indicated as "blooms", and particularly "harmful algal blooms" (HABs) because of their potential to cause illness. Blooms may vary in color from red (so called "red tides") to different shades of yellow, green, brown or blue, or harmless water discolorations, depending on the type of Protista and their depth and concentration [11].

For all these reasons, the shellfish supply chain, schematized in figure 2 , is probably more complex and more controlled than any other foodstuff chain.

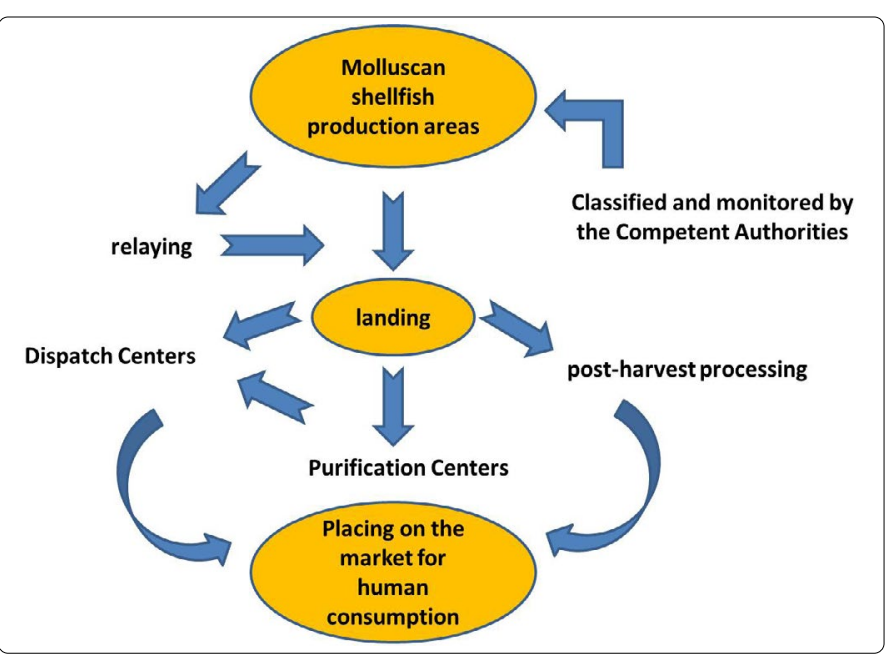

Figure 2. Shellfish supply chain.

In order to protect consumers, two main actions are applied in the supply chain of shellfish, although with some differences depending on the country of production: official classification and monitoring of growing areas, and regulated post-harvest treatments.

The National Shellfish Sanitation Program (NSSP) is the federal/state cooperative program recognized by the U.S. Food and Drug Administration (FDA) and the Interstate Shellfish Sanitation Conference (ISSC) for the sanitary control of shellfish produced and sold for human consumption. The program is operatively implemented by each State Shellfish Control Authority (SSCA). In Europe, the Competent Authorities are designed by each Member State, and in Italy are placed at a local level, under the control of the Region (Regional Sanitary Service) and the supervision of the Ministry of Health (Directorate General for Food Hygiene, Safety and Nutrition).

\section{Foodborne Illnesses related to the consumption of Shellfish}

\section{Viruses and bacteria}

Food borne illnesses related to the consumption of shellfish may be caused by viruses and bacteria of fecal origin, coming from wastewater effluents, as noroviruses (NoVs) and Hepatitis A virus (HAV), Salmonella spp., Shigella spp., Campylobacter spp., Escherichia coli, and autochthonous bacteria of the genus Vibrio, including $V$. parahaemolyticus, $V$. vulnificus, $V$. cholerae 01 and non-O1 serotypes [12]. The illnesses caused by these agents range from mild gastroenteritis to life-threatening syndromes [13]. 
During the last century, the majority of outbreaks attributed to shellfish consumption were associated with bacterial pathogens from fecal pollution, and the primary causative agent was Salmonella spp., however, as a consequence of surveillance programs, typhoid fever has drastically declined in all developed countries [14]. Today, NoVs and HAV are considered among the most common pathogens transmitted by shellfish [15]. This fact is not surprising because enteric viruses are more resistant to wastewater treatment and are more environmentally stable than fecal indicator bacteria [16].

NoVs are genetically divided into 5 genogroups, 3 of which (GI, GII, GIV) are recognized as pathogens for humans, being responsible for mild gastroenteritis [17].

HAV infection is the most serious viral infection linked to shellfish consumption, even if rarely reported, causing debilitating disease and, occasionally, death [18].

Besides the enteric viruses, among the bacterial agents, pathogenic vibrios have emerged as new threats since the 1970s [19], and among them V. cholerae, V. parahaemolyticus and $V$. vulnificus are responsible for the majority of bacterial human infections linked to shellfish consumption $[20,21]$. $V$. cholera is a common inhabitant of marine coastal waters, and actually, more than 200 O-antigen serogroups are recognized, among which only serogroups 01 and 0139 are considered etiologic agents of epidemic and pandemic cholera [22], characterized by a profuse rice water diarrhea. In any case, occasional outbreaks of cholera-like disease in humans are caused by non-01/non-0139 cholera serotypes $[23,24]$. V. parahaemolyticus occurs naturally in the marine environments and in a variety of seafood [25], and is abundant in shellfish samples, being recognized as a common cause of acute gastroenteritis worldwide [26], particularly in the Far East, where raw seafood consumption is commonly practiced [27].

$V$. vulnificus occurs naturally in the marine environments, particularly in warm and medium salinity conditions, but it has been recovered in a wide range of temperatures and salinities [28]. Actually, three biogroups are recognized and differentiated by biochemical characteristics: biogroup 1, which is pathogenic to humans, biogroup 2, which is pathogenic to eels, and biogroup 3, which is pathogenic to humans but has only been reported in Israel [29]. Biogroup 1 infects humans through skin lesions or the ingestion of contaminated seafood, causing respectively wound infection, leading to severe soft tissue necrosis, eventually followed by secondary septicemia, and primary septicemia or, less frequently, gastrointestinal disease [30].

Other species of the genus Vibrio, e.g. V. alginolyticus, $V$. mimicus, Grimontia hollisae (formerly V. hollisae), $V$. cincinnatiensis, V. fluvialis, V. furnisii, $V$. harveyi and $V$. metschnikovii, have been sporadically found in human infections [31].

\section{Marine biotoxins}

About 75 marine species of microscopic algae, notably dinoflagellates and diatoms, belonging to the genera
Alexandrium, Gymnodinium, Dinophysis, and Pseudo-nitzschia [32], have the capacity to produce potent toxins, named phycotoxins, causing a variety of gastrointestinal and neurological illnesses in humans. It is not clear why some microscopic algae produce toxins, secondary metabolites with no explicit role in the internal economy of the organisms, but with very specific activities in mammals [11]. Phycotoxins can bio-accumulate in shellfish, but also in fish, crabs, lobster, and approximately 60,000 human intoxications occur per year worldwide, with an overall mortality of about $1.5 \%$ [33].

There are seven major poisoning syndromes caused by phycotoxins: paralytic shellfish poisoning (PSP); diarrhetic shellfish poisoning (DSP); neurotoxic shellfish poisoning (NSP); amnesic shellfish poisoning (ASP); azaspiracid shellfish poisoning (AZP); ciguatera fish poisoning (CFP); and clupeotoxin fish poisoning (CLP). Over the last decades, the occurrence and intensity of $\mathrm{HAB}$ appear to be increasing on a global scale due to rising ocean temperatures and growing coastal eutrophication [32].

According to the European legislation [34,35], the maximum levels of biotoxins in shellfish destined to human consumption are: PSP $(800 \mathrm{pg} / \mathrm{kg})$, ASP $(20 \mathrm{mg} / \mathrm{kg}$ of domoic acid), DSP: okadaic acid (OA) + dinophysitoxins + pectenotoxins $(160 \mu \mathrm{g}$ OA equivalents $/ \mathrm{kg})$, yessotoxin $(3,75 \mathrm{mg} / \mathrm{kg})$, AZP (160 pg/kg). According to the U.S. system [36], the maximum levels of biotoxins in shellfish are: PSP $(80 \mu \mathrm{g} / 100 \mathrm{~g})$, ASP $(20 \mathrm{mg} /$ $\mathrm{kg})$, DSP (0.16 mg/kg), AZP (0.16 mg/kg), NSP (20 MU/100 g).

\section{Chemical contaminants}

Industrial wastes and mining can create a potential source of chemical contaminants pollution in the aquatic environment, determining a damage of both marine species diversity and ecosystems, due to their toxicity and accumulative behavior. In shellfish, accumulation often occurs in the digestive gland, which plays a role in assimilation, excretion, and detoxification of contaminants [37].

Among the heavy metals, iron, copper, zinc and manganese, are defined "essential metals" since they play important roles in biological systems, producing toxic effects only at high concentrations, whereas mercury, lead and cadmium are toxic, even in trace amounts [38]. Moreover, other contaminants are of concern, and among them: polycyclic aromatic hydrocarbons (PAHs), dibenzo-p-dioxins, dibenzofurans (PCDD/Fs, dioxins), and polychlorinated biphenyls (PCBs) [39].

According to the European legislation, shellfish must comply with maximum levels of certain contaminants as follows: lead $\left(1.5 \mathrm{mg} / \mathrm{kg}^{-1}\right)$, cadmium $\left(1 \mathrm{mg} / \mathrm{kg}^{-1}\right)$, mercury $(0.5$ $\left.\mathrm{mg} / \mathrm{kg}^{-1}\right)$, dioxins $\left(4 \mathrm{pg} / \mathrm{g}^{-1}\right.$ and dioxins + DL-PCBs $\left.8 \mathrm{pg} / \mathrm{g}^{-1}\right)$, and benzo[a]pyrene (10 $\mu$ p. $\left.\mathrm{g} \mathrm{kg}^{-1}\right)$ [37].

It is difficult to compare the US system with the EU system, because the former includes sixteen deleterious substance, excluding biotoxins, and eight chemotherapeutics. Taking into account only the substances provided by EU legislation, in the US the guidance level for mercury is $1.0 \mathrm{ppm}$ and for $\mathrm{PCBs}$ is 2 ppm [36]. 


\section{Classification and Monitoring of Shellfish growing areas}

The microbiological monitoring of shellfish production areas, laid down by national or regional authorities, is mainly based on the quantification of fecal indicator bacteria, according to two principal systems: the European system, and the U.S. system. Some countries have produced hybrid systems in order to comply with both requirements [40].

The European system [41,42], is based on the $E$. coli levels in shellfish flesh and intravalvular liquid as reported in table 1.

Table 1. EU classification criteria of shellfish harvesting area.

\begin{tabular}{|c|c|c|}
\hline $\begin{array}{l}\text { CLASS } \\
\text { AREA }\end{array}$ & $\begin{array}{c}\text { Microbiological standards } \\
\text { Most Probable Number (MPN) for } \\
100 \mathrm{~g} \text { of flesh and intravalvular liquid }\end{array}$ & Treatment required \\
\hline A & $\begin{array}{l}\text { E. coli } \leq 230 \text { MPN } \\
\text { ( } 5 \text { sampling units of which } 1 \text { may exceed } \\
230 \text { MPN, but not } 700 \text { MPN). }\end{array}$ & none \\
\hline B & $\begin{array}{l}\text { E. coli> } 230 \mathrm{MPN} \text { and } \leq 4.600 \mathrm{MPN} \\
10 \% \text { of samples may exceed } 4.600 \mathrm{MPN} \text {, } \\
\text { but not } 46.000 \mathrm{MPN}\end{array}$ & $\begin{array}{l}\text { Depuration or relaying in } \\
\text { class } A \text { area, or approved } \\
\text { heat treatment }\end{array}$ \\
\hline C & E. coli> 4.600 MPN and $\leq 46.000 \mathrm{MPN}$ & $\begin{array}{l}\text { Relaying for a long } \\
\text { period } \\
\text { or approved heat } \\
\text { treatment }\end{array}$ \\
\hline Prohi & on-classified areas & \\
\hline
\end{tabular}

The shellfish harvesting areas are classified as four classes: A, B, C, and Prohibited. Shellfish from class A areas can be harvested and directly destined to human consumption; those from class $B$ areas must be purified through an approved depuration facility (in tanks of clean seawater) or transferred (relayed) in an approved class A relaying area; those from class $C$ areas must be relayed in an approved class $A$ relaying area, for a minimum of two months, and then eventually purified through an approved depuration unit; those from prohibited areas (unclassified by the Competent Authorities, or exceeding the $E$. coli level of class $C$ area) cannot be harvested.

According to the U.S. NSSP, the shellfish harvesting areas are classified as Approved (where harvest for direct marketing is allowed); Conditionally Approved (area which meets the criteria for the approved classification except under certain conditions described in a management plan); Restricted (area where harvesting shall be done by special license and the shellstock, following harvest, is subjected to a suitable and effective treatment process through relaying or depuration); Conditionally Restricted (area that meets the criteria for the restricted classification except under certain conditions described in a management plan); Prohibited (area where the harvest of shellstock for any purpose, except depletion or gathering of seed for aquaculture, is not permitted). The U.S. system is based on the total coliforms and fecal coliforms content of water in the growing areas [36], as reported in table 2.
Table 2. U.S.NSSP classification criteria of shellfish harvesting area.

\begin{tabular}{|c|c|c|c|c|c|}
\hline \multirow[t]{3}{*}{ CLASS AREA } & \multicolumn{4}{|c|}{$\begin{array}{l}\text { Microbiological standards for } 100 \mathrm{ml} \text { of water } \\
\text { Most probable Number (MPN) for } 5 \text {-tube } \\
\text { decimal dilution test - } 90 \text { percent compliance } \\
\text { for the 3-tube MPN and mTEC membrane } \\
\text { filtration tests. }\end{array}$} & \multirow[t]{3}{*}{$\begin{array}{l}\text { Treatment } \\
\text { required }\end{array}$} \\
\hline & \multicolumn{2}{|c|}{ Total coliforms } & \multicolumn{2}{|c|}{ Fecal coliforms } & \\
\hline & $\begin{array}{c}\text { Geometric } \\
\text { Mean }\end{array}$ & $\begin{array}{c}90 \% \\
\text { compliance }\end{array}$ & $\begin{array}{l}\text { Geometric } \\
\text { Mean }\end{array}$ & $\begin{array}{c}90 \% \\
\text { compliance }\end{array}$ & \\
\hline Approved & $\leq 70$ & $\leq 230$ & $\leq 14$ & $\leq 43$ & none \\
\hline $\begin{array}{l}\text { Conditionally } \\
\text { Approved }\end{array}$ & \multicolumn{5}{|c|}{$\begin{array}{l}\text { Survey Required. The area shall meet the requirements for an } \\
\text { approved area classification when the conditionally approved } \\
\text { classification is in the open status }\end{array}$} \\
\hline Restricted & $\leq 700$ & $\leq 2300$ & $\leq 88$ & $\leq 260$ & $\begin{array}{l}\text { Depuration or } \\
\text { relaying in an } \\
\text { approved area }\end{array}$ \\
\hline $\begin{array}{l}\text { Conditionally } \\
\text { Restricted }\end{array}$ & \multicolumn{4}{|c|}{$\begin{array}{l}\text { Survey Required. The area shall meet the } \\
\text { requirements for a restricted classification when } \\
\text { the conditionally restricted classification is in } \\
\text { the open status }\end{array}$} & $\begin{array}{l}\text { Depuration or } \\
\text { relaying in an } \\
\text { approved area }\end{array}$ \\
\hline Prohibited & \multicolumn{4}{|c|}{$\begin{array}{l}\text { Areas with exceeding microbiological values, } \\
\text { and/or with other harmful aspects. }\end{array}$} & \\
\hline
\end{tabular}

The relationship between the two systems has been investigated using both statistical modelling and simple compliance assessment on large international data sets of paired seawater and shellfish samples, showing that EU class A is more stringent than the U.S. Approved category for all species, but the U.S. Restrictive standard is more restrictive than EU class B for some bivalve species (oyster), therefore, the systems are not exactly equivalent [43]. In any case, both the systems establish that shellfish intended for human consumption must comply with the criteria of A (EU system) or Approved (US system) class area.

Moreover, the U.S. NSSP outlines regulations for shellfish harvested during warm water months, contaminated water, or clinical cases associated with Vibrio vulnificus, Vibrio parahaemolyticus, or other human pathogens found in waters near growing areas [36].

This approach is in line with the objective of the Food Safety Modernization Act (FSMA), of the FDA, the most sweeping reform of the U.S. food safety laws in more than 70 years, signed into law on January 4, 2011 (Public Law 111353), with the aim to ensure the U.S. food supply is safe by shifting the focus from responding to contamination to preventing it [44].

With respect to Vibrio vulnificus, Vibrio parahaemolyticus and other pathogens, eventually present in the production areas, no specific actions are laid down by the European legislation in force [41].

According to the European legislation $[41,45]$, and the U.S. NSSP [36], shellfish from the classified areas are sampled for the control of certain biotoxins and chemical pollutants, for which specific limits are provided to comply with the standard for human consumption.

In the U.S., monthly or bimonthly sampling regimes are considered acceptable, to monitor the sanitary status on annual basis and with a triennial reevaluation. Moreover the Competent Authority will require a different sampling plan during particular tidal conditions, if these conditions unfavorably impact the water quality of the growing area [36]. 
According to the European Guide to Good Practice Technical Application [46], the frequencies of the microbiological monitoring of shellfish harvesting areas is established conforming to the state of "initial classification", "primary established classification", "ongoing monitoring <3 years data", "ongoing monitoring $\geq 3$ years data". The suggested frequencies are steadily growing, from a weekly basis of 6 months to a monthly basis over the year. In Italy, any Region may decide the frequencies of sampling and testing of the shellfish growing areas, but, generally, the frequencies for the ongoing monitoring ( $\geq 3$ years data) are: weekly or fortnightly for $H A B$ and marine biotoxins; bi-monthly or quarterly for E. coli and Salmonella spp.; half-yearly for the chemical contaminants.

\section{Post-Harvest Processing Methods}

With the possible exception of fruits and vegetables, seafood including shellfish, may be considered the most widely consumed food category in various states of raw to fully cooked [13]. According to the definitions of the Codex Alimentarius Commission [47,48], shellfish are referred to as: "live" (which are alive at the time of retail), "raw" (when shucked and/or frozen and/or processed while essentially retaining the sensory characteristics of live shellfish), and "processed" (when quick-frozen, breaded, smoked, marinated, salted, dried, shucked, cooked-ready-to-eat, and canned).

Post-harvest Processing (PHP) methods are viable food processing methods employed merely to reduce human pathogens in shellfish, whereas the chemical decontamination of shellfish is not considered achievable by standard treatments to date.

The PHPs applied to live shellfish to allow microbial contaminants to be purged, are the natural depuration in lesscontaminated areas, the so called "relaying", and the controlled "depuration" (or purification) at an authorized depuration center, by immersion in tanks containing clean seawater [14].

Example of PHPs applied to shellfish, that are not sold alive, are thermal processing, freezing and frozen storage, irradiation, and high-hydrostatic pressure (HHP).

According to the U.S. NSSP [36], if PHPs are used to reduce human bacterial pathogens in shellfish, the dealer must process under a seafood hazard analysis critical control point (HACCP) plan and validate that the process achieves a minimum $3.52 \log _{10}$ reduction of viable bacteria and reduces the level of $V$. vulnificus and $V$. parahaemolyticus to nondetectable levels ( $<30 \mathrm{MPN} / \mathrm{g}$ ). On the other hand, the Joint FAO/WHO suggested that effective PHPs should strive to achieve at least a $4-\log _{10}$ reduction in $V$. vulnificus levels which would essentially eliminate illnesses if applied during restricted harvest periods [19].

Unfortunately, it should be outlined that, notwithstanding the epidemiological relevance of enteroviruses and pathogenic vibrios, actually they are not considered by the European legislation among the safety criteria [49], even if contaminated batches, when identified by the Competent
Authority in the post-harvest steps, are considered unsuitable for human consumption and withdrawn from trade.

\section{PHPs for live shellfish: depuration and relaying}

The practice of transferring shellfish to clean waters to allow the natural cleansing of intravalvular sand and other undesired material, has been documented since the XIX century in Mediterranean countries; however, the first commercial plant was only realized in the U.S. in 1922, in an attempt to reduce outbreaks of typhoid fever associated with the consumption of raw shellfish [14].

The European legislation [34] defines "purification center" an establishment with tanks fed by clean seawater in which live bivalve molluscs are placed for the time necessary to reduce contamination to make them fit for human consumption; "dispatch center" any on-shore or off-shore establishment for the reception, conditioning, washing, cleaning, grading, wrapping and packaging of live bivalve molluscs fit for human consumption; "relaying" the transfer of live bivalve molluscs to sea, lagoon or estuarine areas for the time necessary to reduce contamination to make them fit for human consumption.

The U.S. NSSP [36] defines: "depuration" the process of reducing the pathogenic organisms that may be present in shellstock (live shellfish in the shell) by using a controlled aquatic environment as the treatment process; "relay" the transfer of shellstock from a growing area classified as restricted or conditionally restricted to a growing area classified as approved or conditionally approved for the purpose of reducing pathogens as measured by the coliform indicator group or poisonous or deleterious substances that may be present in the shellstock by using the ambient environment as the treatment process.

It is widely recognized that the process of depuration is an effective treatment for shellfish that are moderately contaminated with bacteria of fecal origin, such as E. coli [50], but the effectiveness on Vibrio spp., and viruses is considered very limited [51-53], most probably because these contaminants possess different mechanisms of bioaccumulation and clearance compared to fecal bacteria [54-57].

Therefore, at present, depuration treatment is considered satisfactory when these goals are achieved: the reduction of fecal bacteria, in order to comply with the legislative standards, and the control of microbial colonization of the system, particularly with respect to Vibrio spp. [14].

Basically, the requirements for depuration are: an adequate quantity of clean seawater to supply the tanks of the plant, high-performance of the design and construction of the plant, adequate filtration and disinfection equipment, control of temperature, salinity, turbidity, $\mathrm{pH}$ values and oxygen content of water, quality control of the whole operating cycle, and endproduct microbiological testing [58].

The quality of seawater is very important, because poor quality water may produce additional microbiological contamination of shellfish, and/or the introduction of harmful chemical contaminants. Depending on the kind of plant, the 
tanks may be supplied by water from a static system, or with flow-through from a marine area or recirculating system. In any case, the water needs to be filtered and disinfected prior to and after the operating cycle. A description of the most utilized types of plants has been reported elsewhere [14].

With regard to the relaying practice, only class $A$ areas (EU system) or Approved class areas (U.S. system) may be classified for this purpose by the Competent Authority. It should be noted, anyway, that unlike the depuration under controlled conditions, in the natural environments Vibrio spp. enrichment is obviously possible, because these bacteria are natural inhabitant of seawater, even if it is widely accepted that high salinity conditions may result unfavorable for $V$. vulnificus and $V$. parahaemolyticus abundance, whereas low salinity (5 - 25 ppt) and high temperature $\left(>15-20^{\circ} \mathrm{C}\right)$ are considered promoting factors $[59,60]$. In any case it is important to underline that $V$. vulnificus and $V$. parahaemolyticus distribution in the environment may be linked to different geographic locations [61].

A multi-year retrospective study on $V$. parahaemolyticus and $V$. vulnificus prevalence in the clam Ruditapes philippinarum harvested in Italy, reported a positive correlation $(P<0.05)$ with seawater temperature of the warmer months $\left(>16.45^{\circ} \mathrm{C}\right)$, but not $(P>0.05)$ with the lower values of salinity $(<27$ psu) [62], according to other studies where salinity values resulted only marginally associated or unrelated to $V$. parahaemolyticus and V. vulnificus abundance [63-65]. Moreover the abundance of the subpopulation of $V$. parahaemolyticus possessing the genes encoding for the thermostable direct hemolysin ( $t d h)$, and tdhrelated hemolysin (trh), resulted unrelated with the seawater temperature $[61,62]$.

In any case it has been speculated that using the socalled "high-salinity relaying", namely transferring oysters to other higher salinity waters (30-35 ppt) than those of harvest waters, may produce a reduction of $V$. vulnificus and $V$. parahaemolyticus, and also the transfer into high salinity land-based tanks may give similar results [10].

\section{Thermal processing}

Available epidemiological data are inadequate to determine the relative contributions of raw, undercooked, or properly cooked and then recontaminated seafood, to the burden of foodborne disease. Although a seafood cooking process may reduce the microbiological public health risk associated with the product, the extent of risk reduction differs by type of seafood, the cooking method applied, and the level of microbial pathogens [66].

In any case it is widely recognized that adequate thermal processing may be effective on viruses and pathogenic bacteria in foodstuffs, even if it may causes variable physical, chemical, and biological changes resulting in the reduction of quality [10].

Microorganisms are far more resistant to dry heat than to wet heat, that is the conditions mostly utilized in food microbiology studies. In dry heat treatment, microorganisms seem to be inactivated by oxidation, whereas protein denaturation and membrane damage seems to play an important role in wet heat inactivation [67-69].

Defining the $D$-value as the time needed to inactivate 1 $\log _{10}$ unit of a given pathogen at a specified temperature for a given product, the following are among those indicated by the National Advisory Committee on Microbiological Criteria for Foods (NACMCF) [66] for oyster: 1.3-1.6 min at $50^{\circ} \mathrm{C}$ for V.parahaemolyticus and $39.9^{\circ} \mathrm{C} \pm 1.2 \mathrm{~s}$ for $V$. vunificus (in shucked oyster).

Certain human enteric viruses may be more heat resistant than vegetative bacterial cells and can cause disease at relatively low doses [70]. To date, all attempts to propagate NoVs and wild type strains HAV in routine laboratory cell culture or primary tissue cultures have been unsuccessful $[71,72]$, therefore surrogates for foodborne enteric viruses have been utilized in inactivation studies, including feline calicivirus, murine norovirus, bacteriophage MS2, tulanevirus, sapovirus, poliovirus, HAV. As a consequence, different time/ temperature range of inactivation are reported in the literature. The following viruses are among those indicated by NACMCF [66] for shellfish: Feline Calicivirus (FCV) is reduced of about $4 \log _{10}$ by immersion in boiling water for 1-2 min (mean internal temperature of $78^{\circ} \mathrm{C}$ ); $\mathrm{HAV}$ is reduced of about 3,5 $\log _{10}$ by immersion in boiling water for 3 min (mean internal temperature of $92^{\circ} \mathrm{C}$ ).

The EU legislation [34] states that live shellfish from B and $C$ production areas that have not been submitted for purification or relaying may be sent to a processing establishment, where they must undergo treatment to eliminate pathogenic microorganisms. The prescribed treatments have been imposed to ensure the elimination of pathogenic microorganisms, in particular the Norovirus, possibly present in shellfish. These treatments are: a) sterilization in hermetically sealed containers; b) heat treatments involving i) immersion in boiling water at $90^{\circ} \mathrm{C}$ and maintenance of this minimum temperature in the flash not less than 90 seconds, or ii) cooking for 3-5 minutes in an enclosed space where the temperature is between 120 and $160^{\circ} \mathrm{C}$ and the pressure is between 2 and $5 \mathrm{~kg} / \mathrm{cm}^{2}$, followed by shelling and freezing of the flesh to a core temperature of $-20^{\circ} \mathrm{C}$, or iii) steaming under pressure in an enclosed space satisfying the requirements relating to cooking time and the internal temperature of the mollusc flesh mentioned under (i).

As the major pathogen targeted in the U.S. for oyster is $V$. vulnificus, able to grow between $8-43^{\circ} \mathrm{C}$, FDA recommends boiling live oysters for 3-5 $\mathrm{min}$ after the shell opens or steaming for 4-9 $\min [73]$.

\section{Freezing and frozen storage}

Freezing followed by frozen storage is a method commonly used to preserve product quality by inhibiting growth of bacteria, and has been reported capable of achieving certain degrees of reductions of $V$. parahaemolyticus. Particularly it has been reported that storing oysters for 1 month at $-10^{\circ} \mathrm{C}$ resulted more effective than the storage at $-20^{\circ} \mathrm{C}$ or $-30^{\circ} \mathrm{C}$, in fact $V$. parahaemolyticus load declined by 
$2.45,1.71$, and $1.45 \log _{10} \mathrm{MPN} / \mathrm{g}$ respectively, and continued to decline during a prolonged storage [74], in fact, a reduction of $V$. parahaemolyticus greater than $3.52-\log (\mathrm{MPN} / \mathrm{g})$ was reached after 5 months at $-21^{\circ} \mathrm{C}$ according to the U.S. NSSP [36] postharvest processing validation-verification interim guidance for $V$. vulnificus and $V$. parahaemolyticus.

Moreover, in a previous study it has been reported that 6 months of frozen storage at $-10^{\circ} \mathrm{C}$ produced a reduction of $\mathrm{V}$. parahaemolyticus in oyster (homogenate and inoculated) of 4.55- $\log _{10}$ [75]. On the other hand, it has been reported that different freezing temperatures $\left(-80,-35\right.$, and $\left.-10^{\circ} \mathrm{C}\right)$, did not significantly ( $\alpha=0.05$ ) affect survival of $V$. vulnificus in oyster immediately after freezing, whereas the combined effect of freezing and frozen storage (1 week) resulted in 1.5, 2.6, and $4.9 \log _{10}$ reductions for samples stored at $-80,-35$, and $-10^{\circ} \mathrm{C}$, respectively [76]. These results clearly indicate that storage temperatures, after freezing, are the critical parameters in survival of $V$. vulnificus.

Considering the available data, it seems that to achieve a consistent reduction of pathogenic vibrios, at least in oyster, a prolonged frozen storage is advisable, taking into account that the lower is the temperature of storage, the lower is the damaging effect on the bacterial component. With respect to enteric viruses, freezing tends to represent a conservative treatment, even if there can be an initial loss in virus titer with each freeze-thaw cycle, particularly in minimally contaminated products [77].

\section{Irradiation}

Food irradiation is a process in which irradiation energy, generally gamma radiation from a radioisotope source, or with electrons or X-rays generated using an electron accelerator, is applied to kill microorganisms or insects in foods [78].

This process has proven to be successful, not only in ensuring the safety, but also in extending the shelf-life of foodstuffs because of its high effectiveness in inactivating pathogens without deteriorating product quality [79].

The international unit for absorbed dose is the Gray (Gy), and it depends on the type of food, being indicated as "low" (up to $1 \mathrm{kGy}$ ), "medium" (1-10 kGy), and "high" (greater than 10 kGy).

The effect on shellfish has been tested by many authors, demonstrating a significant extension of the shelf life, and against pathogens as Salmonella spp. and V. parahaemolyticus, particularly at medium doses of irradiation, but with different effects on the quality of shellfish meat, ranging from no detectable organoleptic differences between irradiated (at 2.5, 5.5 and up to $8 \mathrm{kGy}$ ) and non-irradiated controls, to the observation of soft, spongy, and mushy texture, or undesirable odors in treated shellfish [78].

The U.S. NSSP [36] recognizes Vibrio reduction processes such as irradiation (to an absorbed dose no greater than 5.5 $k G y$ ), and provides general requirements for dealers using them. Irradiation facilities must utilize a process that has been validated in accordance with the NSSP to achieve a reduction of V.vulnificus and/or V.parahaemolyticus to less than 30
MPN/g. The shellfish processor and the irradiation facility must have implemented a HACCP plan, approved for the process, that ensures the target pathogen (s) in shellfish are consistently reduced to levels recognized as safe in the NSSP Model Ordinance [36].

Since the 1999, the EU attempted to harmonize the different Member States laws relating to the ionizing radiations of food through two Directives [80,81], authorizing the treatment only for dried aromatic herbs, spices and vegetable seasonings (maximum dose $10 \mathrm{kGy}$ ), but enabling Member States to continue to apply the pre-existing national legislation. Therefore, considerable differences still exist. In any case the irradiation of food in Europe is quite marginal with respect to the U.S. and Japan, being applied mostly to frog legs $(54,75 \%)$, herbs and spices $(16,10 \%)$, poultry $(15,46 \%)$, de-hydrated vegetable and fruit $(8,53 \%)$, frozen shrimp (0,95\%). Belgium is the leading country applying the irradiation, accounting for about $70 \%$ of all the treated food [82].

\section{High-hydrostatic pressure}

The effect of the high-hydrostatic pressure (HHP) on microorganism reduction was first postulated in 1899, but it was only in late 1980 's that its commercial benefits became available to the food processing industries. Under HHP, all metabolic tissues are processed in a closed vessel that applies high pressure equally and at the same time to minimize moisture loss and eventual product quality [10].

The advantage of this treatment is that it enables food processing at ambient temperature or even lower temperatures, causing microbial death whilst virtually eliminating heat damage and the use of chemical preservatives/additives, thereby leading to improvements in the overall quality of foods [83].

With respect to shellfish, it has been established that exposing oysters to carbon dioxide $\left(\mathrm{CO}_{2}\right)$ at 100 bar and $37^{\circ} \mathrm{C}$ for 30 minutes and at 172 bar and $60^{\circ} \mathrm{C}$ for 60 minutes, induced a significant reduction ( $P=0.002)$ in the Aerobic Plate Count, with $2-\log _{10}$ and $3-\log 10$ of reductions respectively [84].

Moreover, Vibrio spp. appear to be more susceptible to HHP than other bacteria found in oysters [10], even if with some differences among different strains: $V$. vulnificus naturally occurring in oysters achieved more than $5 \log _{10}$ reduction at a pressure treatment of $250 \mathrm{MPa}$ for $120 \mathrm{~s}$, whereas $V$. parahaemolyticus serotype 03:K6 and $V$. cholerae non-O1 required a pressure of at least $300 \mathrm{MPa}$ for $180 \mathrm{~s}$ for a comparable $5 \log _{10}$ reduction [85].

HHP is also known to inactivate human viruses found in the tissues of shucked oysters, mussels, and clams, therefore it is currently the favored method of post-harvest processing of shellfish in the Southeastern U.S. [10].

\section{Concluding Remarks}

Fish and fishery products are at the forefront of food safety and quality improvement because they are among the most internationally traded food commodities. Despite its 
benefits, seafood consumption can cause infections, or intoxications, the former more common in countries with high row seafood consumption, particularly shellfish [86]. In this review only the EU and U.S. systems of requirements and official controls have been considered, but it can be said that many other countries have produced hybrid systems, as is the case of New Zealand, where fecal indicators standards for water (as in the U.S. system) and shellfish (as in the European system) have been both established by the NZFSA (New Zealand Food Safety Authority) for the growing areas [87].

There is no doubt that as a consequence of the surveillance programs, typhoid fever attributed to shellfish consumption has drastically declined in all developed countries [14]. On the other hand the surveillance of the growing areas, mainly based on fecal indicators, does not provide information on the prevalence of enterovirus and pathogenic vibrios, representing the leading cause of infection if shellfish are consumed raw or undercooked. In fact the abundance of these agents is unrelated to the fecal indicators, with the possible exception of toxigenic $V$. cholerae 01 [62,88].

As opposed to the EU Legislation $[41,42]$, the U.S. NSSP outlines regulations on the control of Vibrio vulnificus and Vibrio parahaemolyticus in the growing areas [36], at least during warm water months, when the environmental conditions are more favorable to their growth. In any case it should be noted that these bacteria may be stimulated by other environmental factors, and $V$. vulnificus has been isolated in a wide range of temperatures and salinities [28], therefore the water temperature may be not the only predictive factor.

With respect to the PHTs applied to live shellfish, it is well documented that the depuration treatment does not ensure the reduction/elimination of pathogenic vibrios, and enteric viruses as well [14,51-53]. As a consequence, the consumption of raw or undercooked shellfish may be hazardous even if shellfish have been submitted to purification.

It has been reported that the immersion in waters with high salinity value seems to offer a possible solution for the reduction of $V$. parahaemolyticus and $V$. vulnificus in oyster [10], but the mechanism behind this effect has not been explained and more studies are needed on different species other than oyster.

Only PHPs applied to shellfish that are not sold alive, particularly adequate thermal processing, irradiation, highhydrostatic pressure, and prolonged frozen storage, may be actually considered effective to make the shellfish consumption safe from biological agents.

Giving that shellfish, and particularly oyster, are preferred fresh (alive) at retail, being commonly eaten raw or lightly cooked, their consumption continue to be a public health problem, as much from a social as from an economic point of view, therefore there is a strong need to develop PHPs able to ensure adequate control of biological contaminants possibly without impairment of shellfish viability.

Lastly, it should be outlined that, at present, no postharvest treatment has proven to be successful on chemical contaminants and biotoxins, therefore only the regular monitoring of growing areas represent a reliable approach for the prevention of intoxications/poisoning.

\section{Acknowledgments}

The author is thankful to Department of Veterinary Medical Science - University of Bologna, Italy, for the financial support.

\section{Conflict of interest}

The author confirm that there is no conflicts of interest regarding this manuscript.

\section{References}

1. Benkendorff K. Molluscan biological and chemical diversity: secondary metabolites and medicinal resources produced by marine molluscs. Biol Rev. 2010; 85(4): 757-775. doi: 10.1111/j.1469-185X.2010.00124.x

2. FAO. Food and Agriculture Organization of the United Nations. The state of world fisheries and aquaculture opportunities and challenges. FAO, Rome, 2014. Accessed September 25, 2017.

3. EUMOFA. European Market Observatory for Fisheries and Aquaculture Products. The EU fish market 2016. European Commission; 2016. Accessed September 25, 2017.

4. Clarke S. Inside the United States: The fish and seafood trade. Global analysis report. Agriculture and Agri-Food Canada, Ottawa, Canada; 2015. Accessed September 25, 2017.

5. Santhanam R. Biology and ecology of edible marine bivalve molluscs. Apple Academic Press. NJ, USA, 2017; 435.

6. FAO. Food and Agriculture Organization of the United Nations. The state of world fisheries and aquaculture. FAO, Rome, 2016. Accessed September 25, 2017.

7. FAO. Food and Agriculture Organization of the United Nations. Globefish highlights. A quarterly update on world seafood markets. FAO, Rome, 2017. Accessed September 25, 2017.

8. EUMOFA. European Market Observatory for Fisheries and Aquaculture Products. The EU fish market 2015. EUMOFA. European Commission. 2016. Accessed September 25, 2017.

9. Dong FM. The nutritional value of shellfish. National Oceanic and Atmospheric Administration (NOAA). Washington Sea Grant, Seattle, WA, 2001. Accessed September 25, 2017.

10. Baker GL. Food safety impacts from post-harvest processing procedures of molluscan shellfish. Foods. 2016; 5(2): 29. doi: 10.3390/foods5020029

11. FAO. Food and Agriculture Organization of the United Nations. Marine Biotoxins. Food and Nutrition Paper 80. FAO, Rome, 2004. Accessed September 25, 2017.

12. Graczyk TK, Suresh K, Lees D. Adverse health outcomes. In: Rees G, Pond K, Kay D, Bartram J, \& Santo Domingo J, eds. Safe management of shellfish and harvest waters. London, UK: WHO and IWA; 2010: 21-38. Accessed September 25, 2017.

13. Iwamoto M, Ayers T, Mahon BE, Swerdlow DL. Epidemiology of seafoodassociated infections in the United States. Clin Microbiol. 2010; 23(2): 399411. doi: 10.1128/CMR.00059-09

14. Serratore $P$, Ciulli S, Piano A, Cariani A. Criticism of the purification process of bivalve shellfish. Literature review and our industrial research experiences. In: Hay RM, ed. Shellfish, human consumption health implication and conservation concerns. Nova Publishers, NY, USA, 2014: 1-50.

15. Potasman I, Paz A, Odeh M. Infectious outbreaks associated with bivalve shellfish consumption: a worldwide perspective. Clin Infect Dis. 2002; 35(8): 921-928. doi: 10.1086/342330

16. Baggi F, Demarta A, Peduzzi R. Persistence of viral pathogens and bacteriophages during sewage treatment: lack of correlation with indicator bacteria. Res Microbiol. 2001; 152: 743-751. doi: 10.1016/S0923- 


\section{8(01)01255-4}

17. Partridge DG, Evans CM, Raza M, Kudesia G, Parsons HK. Lessons from a large norovirus outbreak: impact of viral load, patient age and ward design on duration of symptoms and shedding and likelihood of transmission. J Hosp Infect. 2012; 81(1): 25-30. doi: 10.1016/j. jhin.2012.02.002

18. Pintó RM, Costafreda MI, Bosch A. Risk assessment in shellfish-borne outbreaks of Hepatitis A. Appl Environ Microbiol. 2009; 75: 7350-7355. doi: 10.1128/AEM.01177-09

19. DePaola A, Lee R, Mahoney D, Rivera I,Tamplin M. Case study: Vibrio vulnificus in oysters. In: Background paper for the joint FAO/WHO expert consultation on development of practical risk management strategies based on microbiological risk assessment outputs. FAO, Rome, 2006: $1-30$.

20. Bauer A, Ostensvik O, Florvag M, Ormen O, Rorvik LM. Occurrence of Vibrio parahaemolyticus, V. cholerae, and V. vulnificus in Norwegian Blue Mussels (Mytilus edulis). Appl Environ Microbiol. 2006; 72(4): 3058-3061. doi: 10.1128/AEM.72.4.3058-3061.2006

21. Bauer A, Rorvik LM. A novel multiplex PCR for the identification of Vibrio parahaemolyticus, Vibrio cholerae and Vibrio vulnificus. Lett Appl Microbiol. 2007; 45(4): 371-375. doi: 10.1111/j.1472-765X.2007.02195.x

22. Pang B, Yan M, Cui Z, et al. Genetic diversity of toxigenic and nontoxigenic Vibrio cholerae serogroups 01 and 0139 revealed by array-based comparative genomic hybridization. J Bacteriol. 2007; 189(13): 4837-4849. doi: 10.1128/JB.01959-06

23. Fykse EM, Skogan G, Davies W, Strand Olsen J, Blatny JM. Detection of Vibrio cholerae by real time Nucleic Acid Sequence-Based Amplification. Appl Environ Microbiol. 2007; 73(5): 1457-1466. doi: 10.1128/AEM.0163506

24. Ottaviani $D$, Leoni $F$, Rocchegiani $E$, et al. Prevalence and virulence properties of non-O1 non-O139 Vibrio cholerae strains from seafood and clinical samples collected in Italy. Int J Food Microbiol. 2009; 132(1): 47-53. doi: 10.1016/j.jijfoodmicro.2009.03.014

25. Su YC, Liu C. Vibrio parahaemolyticus: A concern of seafood safety. Food Microbiol. 2007; 24(6): 549-558. doi: 10.1016/j.fm.2007.01.005

26. Ward LN, Bej AK. Detection of Vibrio parahaemolyticus in shellfish by use of multiplexed real time PCR with TaqMan fluorescent probes. Appl Environ Microbiol. 2006; 72(3): 2031-2042. doi: 10.1128/AEM.72.3.2031-2042.2006

27. Nair GB, Ramamurthy T, Bhattacharya SK, Dutta B, Takeda Y, Sack DA. Global dissemination of Vibrio parahaemolyticus serotype O3: $\mathrm{K} 6$ and its serovariants. Clin Microbiol Rev. 2007; 20(1): 39-48. doi: 10.1128/CMR.00025-06

28. Harwood VJ, Gandhi JP, Wright AC. Methods for isolation and confirmation of Vibrio vulnificus from oysters and environmental sources: a review. J Microbiol Methods. 2004; 59(3): 301-316. doi: 10.1016/j.mimet.2004.08.001

29. Nishibuchi M, DePaola A. Vibrio species. In: Fratamico PM, Bhunia AK Smith JL (eds). Foodborne Pathogens: Microbiology and Molecular Biology. Horizon Scientific Press, Norfolk, UK; 2008: 251-271.

30. Ruppert J, Panzig B, Guertler L, et al. Two cases of severe sepsis due to Vibrio vulnificus wound infection acquired in the Baltic Sea. Eur J Clin Microbiol Infect Dis. 2004; 23(12): 912-915. doi: 10.1007/s10096-004-1241-2

31. Thompson FL, lida T, Swings J. Biodiversity of vibrios. Microbiol Mol Biol Rev. 2004; 68(3): 403-431. doi: 10.1128/MMBR.68.3.403-431.2004

32. Visciano $P$, Schirone $M$, Berti $M$, et al. Marine biotoxins: occurrence, toxicity, regulatory limits and reference methods. Front Microbiol. 2016; 7: 1051. doi: 10.3389/fmicb.2016.01051

33. Ajani P, Harwood DT, Murray SA. Recent trends in marine phycotoxins from Australian coastal waters. Mar Drugs. 2017; 15(2): 33. doi:10.3390/ md15020033

34. Regulation (EC) no 853/2004 of the European Parliament and of the Council of 29 April 2004 laying down specific hygiene rules for food of animal origin. Official Journal of the European Union, L226, 22-82.

35. Regulation (EU) no 786/2013 of the European Parliament and of the Council as regards the permitted limits of yessotoxins in live bivalve molluscs. Official Journal of the European Union, L 220, 14

36. National Shellfish Sanitation Program. Guide for the control of molluscan shellfish. Rev 2015 UPD February 2017. U.S. Food and Drug Administration Accessed September 25, 2017.

37. Guéguen $\mathrm{M}$, Amiard $\mathrm{JC}$, Arnich $\mathrm{N}$, et al. Shellfish and residual chemical contaminants: hazards, monitoring, and health risk assessment along French coasts. Rev Environ Contam Toxicol. 2011; 213: 55-111. doi 10.1007/978-1-4419-9860-6_3

38. Sivaperumal P, Sarkar TV, Nair Viswanathan PG. Heavy metal concentration in fish, shellfish and fish products from international markets of India visà-vis international standards. Food Chem. 2007; 102(3): 612-618. doi: 10.1016/j.foodchem.2006.05.041

39. Holland J, Brereton N, Fernandes MR. Chemical contaminant sampling and analysis of shellfish from classified harvesting areas. Report to the Food Standards Agency. Food Standards Agency, UK, London, 2015 Accessed September 25, 2017

40. Lee R, Murray L. Components of microbiological monitoring programmes. In: Rees G, Pond K, Kay D, Bartram J, Santo Domingo J (eds). Safe Management of Shellfish and Harvest Waters. World Health Organization (WHO). London, UK: IWA pbs; 2010: 91-108.

41. Regulation (EC) no 854/2004 of the European Parliament and of the Council of 29 April 2004 laying down specific rules for the organization of official controls on products of animal origin intended for human consumption. Official Journal of the European Union, L226, 83-127.

42. Regulation (EU) no 2285/2015 of the Commission amending Annex II to Regulation (EC) No 854/2004 of the European Parliament and of the Council laying down specific rules for the organisation of official controls on products of animal origin intended for human consumption as regards certain requirements for live bivalve molluscs, echinoderms, tunicates and marine gastropods and Annex I to Regulation (EC) No 2073/2005 on microbiological criteria for foodstuffs. Official Journal of the European Union, L 323, 2-4.

43. Lee RJ, Reese RA. Relating the bivalve shellfish harvesting area classification criteria in the United States and European Union programmes. J Water Health. 2014; 12(2): 280-287. doi: 10.2166/wh.2013.128

44. Food and Drug Administration. Full Text of the Food Safety Modernization Act (FSMA). US FDA, 2014. Accessed September 25, 2017.

45. Regulation (EC) no 1881/2006 of the Commission of 19 December 2006 setting maximum levels for certain contaminants in foodstuffs. Official Journal of the European Union, L 364, 5-24.

46. Centre for Environment, Fisheries and Aquaculture Science. Microbiological monitoring of bivalve mollusc harvesting areas. Guide to good practice: technical application. 2017. Accessed September 25, 2017.

47. Codex Alimentarius Commission. Report of the twenty-fifth session of the Codex Committee on fish and fishery products. Alinorm 03/18. Codex Alimentarius Commission; 2002. Accessed September 25, 2017.

48. Codex Alimentarius Commission. Standard for live and raw bivalve molluscs Codex Stan 292-2008 Adopted in 2008. Amendment: 2013. Revision: 2014 and 2015. Codex Alimentarius Commission; 2008. Accessed September 25, 2017.

49. Regulation (EC) no 2073/2005 of the European Parliament and of the Council of 15th November 2005 on microbiological criteria for foodstuffs. Official Journal of the European Union, L338, 1-26.

50. Jackson $\mathrm{KL}$, Ogburn DM. Review of depuration and its role in shellfish quality assurance. New South Wales shellfish quality assurance program (NSW). Fisheries Final Report Series No. 13; 1999. Accessed September 25, 2017.

51. World Health Organization - Food and Agriculture Organization of the United Nations. Risk assessment of Vibrio spp. in seafood. In: Risk assessment of Campylobacter spp. in broiler chickens and Vibrio spp. in seafood. FAO Food and Nutrition Paper, 75; 2003. Accessed September 25, 2017.

52. Ueki $Y$, Shoji M, Suto A, et al. Persistence of caliciviruses in artificially contaminated oysters during depuration. Appl Environ Microbiol. 2007; 


\section{3(17): 5698-5701. doi: 10.1128/AEM.00290-07}

53. Food and Agriculture Organization of the United Nations. Bivalve depuration: fundamental and practical aspects. Lee $\mathrm{R}$, Lovatelli $\mathrm{A}$, \&Ababouch, L, eds. FAO Fisheries Technical Paper 511. FAO, Rome, Italy; 2008. Accessed September 25, 2017.

54. Nappier SP, GraczykTK, Schwab KJ. Bioaccumulation, retention, and depuration of enteric viruses by Crassostrea virginica and Crassostrea ariakensis oysters. Appl Environ Microbiol. 2008; 74(22): 6825-6831. doi: 10.1128/AEM.01000-08

55. Love DC, Lovelace GL, Sobsey MD. Removal of Escherichia coli, Enterococcus fecalis, coliphage MS2, poliovirus, and hepatitis A virus from oysters (Crassostrea virginica) and hard shell clams (Mercinaria mercinaria) by depuration. Int J Food Microbiol. 2010; 143(3): 211-217. doi: 10.1016/j. ijfoodmicro.2010.08.028

56. Herrfurth $\mathrm{D}$, Oeleker $\mathrm{K}$, Pund RP, et al. Uptake and localization of Vibrio cholerae, Vibrio parahaemolyticus, and Vibrio vulnificus in blue mussels (Mytilus edulis) of the Baltic Sea. J Shellfish Res. 2013; 32(3): 855-859. doi: 10.2983/035.032.0329

57. Le Guyader FS, Atmar RL, Le Pendu J. Transmission of viruses through shellfish: when specific ligands come into play. Curr Opin Virol. 2012; 2(1): 103-110. doi: 10.1016/j.coviro.2011.10.029

58. Food and Agriculture Organization of the United Nations.Bivalve depuration: fundamental and practical aspects. Lee $R$, Lovatelli $A$, \& Ababouch L, eds. FAO Fisheries Technical Paper 511. FAO, Rome, Italy, 2008. Accessed September 25, 2017.

59. Givens CE, Bowers JC, DePaola A, Hollibaugh JT, Jones JL. Occurrence and distribution of Vibrio vulnificus and Vibrio parahaemolyticus - potential roles for fish, oyster, sediment and water. Lett ApplMicrobiol. 2014; 58(6): 503-510. doi: 10.1111/lam.12226

60. Urquhart EA, Jones $\mathrm{SH}, \mathrm{Yu} J \mathrm{~J}$, et al. Environmental conditions associated with elevated Vibrio parahaemolyticus concentrations in Great Bay Estuary, New Hampshire. PLoS One. 2016; 11: e0155018. doi: 10.1371/ journal.pone. 0155018

61. Johnson CN, Bowers JC, Griffitt KJ, et al. Ecology of Vibrio parahaemolyticus and Vibrio vulnificus in the Coastal and Estuarine Waters of Louisiana, Maryland, Mississippi, and Washington (United States). Appl Environ Microbiol. 2012; 78(20): 7249-7257. doi: 10.1128/AEM.01296-12

62. Serratore $\mathrm{P}$, Ostanello $\mathrm{F}$, Passalacqua $\mathrm{PL}$, et al. First multi-year retrospective study on Vibrio parahaemolyticus, and Vibrio vulnificus prevalence in Ruditapes philippinarum harvested in Sacca di Goro, Italy. Ital J Food Saf. 2016; 5(4): e6161. doi: 10.4081/ijfs.2016.6161

63. Parveen $\mathrm{S}$, Jahncke $\mathrm{M}$, Elmahdi $\mathrm{S}$, et al. High salinity relaying to reduce Vibrio parahaemolyticus and Vibrio vulnificus in Chesapeake Bay oysters (Crassostrea virginica). J Food Sci. 2017; 82(2): 484-491. doi: 10.1111/1750-3841

64. Parvathi A, Kumar HS, Karunasagar I, Karunasagar I. Detection and enumeration of Vibrio vulnificus in oysters from two estuaries along the southwest coast of India, using molecular methods. Appl Environ Microbiol. 2004; 70(11): 6909-6913. doi: 10.1128/AEM.70.11.6909-6913.2004

65. Deepanjali A, Kumar HS, Karunasagar I. Seasonal variation in abundance of total and pathogenic Vibrio parahaemolyticus bacteria in oysters along the southwest coast of India. Appl Environ Microbiol. 2005; 71(7): 3575-80. doi: 10.1128/AEM.71.7.3575-3580.2005

66. National Advisory Committee on Microbiological Criteria for Foods. Response to the questions posed by the Food and Drug Administration and the National Marine Fisheries Service regarding determination of cooking parameters for safe seafood for consumers. J Food Prot. 2008; 71: 1287-1308.

67. Setlow B, Setlow P. Heat killing of Bacillus subtilis spores in water is not due to oxidative damage. Appl Environ Microbiol. 1998; 64(10): 4109-4112.

68. Coleman WH, Chen D, Li YQ, Cowan AE, Setlow P. How moist heat kills spores of Bacillus subtilis. J Bacteriol. 2007; 189(23): 8458-8466. doi: 10.1128/JB.01242-07

69. Zhang PF, Kong L, Setlow $P$, Li YQ. Characterization of wet-heat inactivation of single spores of Bacillus species by dual trap Raman spectroscopy and elastic light scattering. Appl Environ Microbiol. 2010; 76(6): 1796-1805. doi:
10.1128/AEM.02851-09

70. D'Souza DH, Moe CL, Jaykus AL. Foodborne viral pathogens. In: Doyle MP, Beuchat LR (eds). Food microbiology: Fundamentals and frontiers. 3rd edition. Washington DC: ASM Press; 2007: 581-607.

71. Duizer E, Bijkerk P, Rockx, B, de Groot A, Twisk F, Koopmans M. Inactivation of caliciviruses. Appl Environ Microbiol. 2004; 70(8): 4538-4543. doi: 10.1128/AEM.70.8.4538-4543.2004

72. Richards GP. Critical review of norovirus surrogates in food safety research: rationale for considering volunteer studies. Food Environ Virol. 2012; 4(1): 6-13. doi: 10.1007/s12560-011-9072-7

73. Food and Drug Administration. The danger of eating contaminated raw oysters. US FDA; 2009.

74. Liu C, Lu J, Su YC. Effects of flash freezing, followed by frozen storage, on reducing Vibrio parahaemolyticus in Pacific raw oysters (Crassostrea gigas).J J Food Prot. 2009; 72(1): 174-177. doi: 10.4315/0362-028X-72.1.174

75. Muntada-Garriga JM, Rodriguez-Jerez JJ, Lopez-Sabater El, Mora-Ventura MT. Effect of chill and freezing temperatures on survival of Vibrio parahaemolyticus inoculated in homogenates of oyster meat. Lett Appl Microbiol. 1995; 20(4): 225-227. doi: 10.1111/j.1472-765X.1995.tb00433.x

76. Seminario DM, Balaban MO, Rodrick G. Inactivation kinetics of Vibrio vulnificus in phosphate-buffered saline at different freezing and storage temperatures and times. J Food Sci. 2011; 76(2): E232-E239. doi: 10.1111/j.1750-3841.2010.02036.x

77. Richards GP, McLeod C, Le Guyader FS. Processing strategies to inactivate enteric viruses in shellfish. Food Environ Virol. 2010; 2(3): 183-193. doi: $10.1111 / 1541-4337.12154$

78. Arvanitoyannis IS, Stratakos A, Mente E. Impact of irradiation on fish and seafood shelf life: a comprehensive review of applications and irradiation detection. Crit Rev Food Sci Nutr. 2008; 49(1): 68-112. doi: 10.1080/10408390701764278

79. Mahapatra AK, Muthukumarappan K, Julson JL. Applications of ozone, bacteriocins and irradiation in food processing: A review. Crit Rev Food Sci Nutr. 2005; 45: 447-461. doi: 10.1080/10408390591034454

80. Directive 1999/2/EC of the European Parliament and of the Council of 22 February 1999 on the approximation of the laws of the Member States concerning foods and food ingredients treated with ionising radiation. Official Journal of the European Communities L66, 16-22.

81. Directive 1999/3/EC of the European Parliament and of the Council of 22 February 1999 on the establishment of a Community list of foods and food ingredients treated with ionising radiation. Official Journal of the European Communities L66, 24-25.

82. EU Commission. Report from the Commission to the European Parliament and the Council on food and food ingredients treated with ionising radiation for the year 2015. 2016.

83. Rastogi NK, Raghavarao KSMS, Balasubramaniam VM, Niranjan K, Knorr D. Opportunities and challenges in High Pressure Processing of foods. Crit Rev Food Sci Nutr. 2007; 47: 69-112. doi: 10.1080/10408390600626420

84. Meujo DAF, Kevin DA, Peng J, et al. Reducing oyster-associated bacteria levels using supercritical fluid $\mathrm{CO} 2$ as an agent of warm pasteurization. Int $\mathrm{J}$ Food Microbiol. 2009; 138(1-2): 63-70. doi: 10.1016/j.ijfoodmicro.2009.11.012

85. Cook DW. Sensitivity of Vibrio species in phosphate-buffered saline and in oysters to high-pressure processing. J Food Prot. 2003; 66(12): 22762282. doi: $10.4315 / 0362-028 X-66.12 .2276$

86. Galaviz-Silva L, Goméz-Anduro G, Molina-Garza ZJ, Ascencio-Valle F. Food safety issues and the microbiology of fish and shellfish. In: Heredia N, Wesley I, García S. Microbiologically Safe Foods. John Wiley \& Sons, Inc. 2008: 227-254. doi: 10.1002/9780470439074.ch11

87. New Zealand Food Safety Authority. Animal Products (Specifications for Bivalve Molluscan Shellfish). Notice 2006. Ministry of Agriculture and Forestry, Wellington, NZ; 2006.

88. DePaola A, Jones JL, Woods J, et al. Bacterial and viral pathogens in live oysters: 2007 United States Market Survey. Appl Environ Microbiol. 2010; 76(9): 2754-2768. doi: 10.1128/AEM.02590-09 